fow yards at a time on level ground. As the invalid gets stronger the length of his walk is gradually increased; be then attempts a gentle up-hill walk, and in time he is able to take long walks up even steep hills with advantage. He is, however, never allowed to walk quickly about two miles an hour is a very good regulation pace for most. He must never put himself out of breath by his exertious, and should stop directly he begins to feel fatigued. Prolonged fatigue, profuse perspiration from the walk. a decidediy raised pulse-rate or respiratory-rate, show that the exercise has been too much. If patients come in chilled from their walk, brisk friction with a warm towel, or a little digestive warm food, will often set them right. With a few exceptions patients should rest for half an hour or more before every important meal, and for an hour after. The most active exercise is best taken in the morning. (Loc. cit.) 4 I have gone more thoroughly into this subject in my work on The Relation of the Chest Movements to Prognosis in Lung.Disease, especially pp. 64 to 68 . 5 Lancet, June roth, $\mathbf{8} 89$, pp. $1552 \cdot 56$

\section{PRESIDENTIAL ADDRESSES}

$$
\text { TO THE }
$$

\section{BRANCHES OF THE BRITISH MEDICAL ASSOCIATION.}

\author{
METROPOLITAN COUNTIES BRANCH.
}

\section{THE ORgANISATION OF THE PROFESSION.}

By Thomas Bryant, M.Ch., F.R.C.S.Eng.,

Consulting Surgeon to Guy's Hospital : Representative of the Royal College of Surgeons of England on the General Medical Council.

The Profession and the Public.

I FERL now, as I have ever felt, that this great association of medical men is a pregnant fact, and that it ought to be a nseful and active factor in moulding public as well as professional opinion into such lines as should be conducive to pablic and professional interests. For whilst with us professional interests must naturally take the first place in our thoughts, it should never be forgotten that the main purpose of our existence as a profession is for the public advantage, and that from such a point of view all our actions will be estimated by the world at large. Under these circumstanees it is important that in all we do, or attempt to do, either as individuals or in combination, we should be studious to avoid, even in appearance, everything which might seem to the nonprofessional mind to savour of professional rather than of public advantage; and we should never forget that we are professional men and not tradesmen, so that not being wageearners we may guard ourselves against being misled into following the methods of those who are, and who at times seem to be working for ends which appear selfish and from motives which sometimes seem unworthy.

And yet there are evils in the pursuit of our calling which want a remedy; some are connected with our public relations, others are more associated with our own body ; for it is said that things are now done in daily practice which should not be done, since they degrade the men who do them in the eyes of the profession, and at the same time lower the profession in public esteem, and thus harm is brought about in both professional and public interests ; for surely the interests of the profession and of the public are identical when the profession advances in skill, knowledge, and che racter the public prospers with it, when the profession sleeps or lapses into bad ways the public suffers. The elevating influence of a clever and good doctor in a small town or village is fully and generally recognised, as well as the unhappy influence of what must be described as the professionally indifferent, casual, or trade doctor. It is important, therefore, for the public to be taught to understand that, since it is in its interests medical men should maintain a high tone of professional morality, so it is in the same interests that no scheme or custom which is calculated to lower the position or depreciate the value of the medical profession in the person of any one of its members should be encouraged or receive public support.

Under these circumstances no blame can be brought against those who seek for means to either relieve or cure the troubles which affect our body, and I believe it will be our best policy to amend our ways where amendment is called for before we venture to touch public interest, for by so doing we shall place ourselves in a better position to influence the public in our favour and to induce it to look at professional matters in a more friendly way. For public opinion is beginning to appreciate the value to the community of past professional scientific work in the way of the prevention and cure of disease and of the relief of pain, and under such circumstances it is less. likely than it may have been to depreviate the value of our services if we be true to ourselves and to the profession of our adoption.

Some of our professional friends, to carry out these objects, would rely upon the reform of the Medical Acts and of the General Medical Council with the view of protecting duly qualified men from unfair competition from without; whilst others look to the great medical corporations for assistance, and ask them not only to employ to the full the disciplinary powers they possess to cleanse our body from within, but to obtain more powers should their present not prove efficient, and all parties seem to call for organisation, which is not only to be applied to compel the councils of the colleges and corporations to protcct the so-called privileges of their own members, but organisation amongst themselves to enable them to apply such remedies to the diseases they recognise as circumstances may require.

The cries for help to the medical corporations and the General Medical Council, with the suggestions to reform the Medical Acts, have to my mind something humorous in their nature-although some improvement in the Medical Acts may reasonably be called for-for they are made without the slightest reference to the objects for which the corporations or General Medical Council were originally created and without taking into account the time which would be expended and the serious difficulties which would be encountered for these bodies to obtain fresh powers, even if they could be induced to apply for them. They forget also the insuperable difficulties which would be raised in Parliament against any laws which might interfere, in a public point of view, with the "Jiberty of the subject."

Indeed, these cries remind me of some sayings of Sidney Smith:- "When A, sees B, in grievous distress, his conscience always urges him toentreat C. to help him," and that the strongest test of the power of a charity sermon is made manifest when the sermon has so influenced a hearer as to induce him to put his hand into his neighbour's pocket in order that he himself might subscribe liberally to the cause adwocated. In fact, gentlemen, it seems that we are all so prone to make other people do their duty, that we are apt under excitement to forget what we can do ourselves, and to throw upon such bodies as corporations and councils duties which do not rightly appertain to them.

With respect to the General Medical Council, I would ask you to recognise that it is a body which was created in 1858 in the interests of the public to regulate the qualifications of practitioners in mrdicine and surgery, and to enable the public to distinguish qualified from ungualified men. It has no other name than the General Council of Medical Education and Registration, and no other disciplinary powers than those required for keeping the Register pure, for which purpose it was given the power of striking off the Regrster or of suspending the name of any medical practitioner who has been convicted of felony, or been found guilty of what the Council considers "infamous conduct."

It has nothing whatever to do with regulating professional action or competition, except with reference to registration, and under these circumstances the Council always takes a public rather than a professional view of every case or subject that comes before it for judgment. Acting on this principle the Council, having for years set its face against the employment of unqualified assistants doing the work of qualified men, has finally pronounced in a very definite way against "covering" and the employment of unqualified assistants; this conclusion having been based upon the view that such a practice was primarily injurious to public interests and seconuarily to professional. On the same principle the Council protects titles. so that the public should not be misled by any and with a like object it has lately taken up the question of medical aid associations, and appointed a committee of its body, of which I am one, to report upon the subject, and particularly in its public aspect, and in the work of the Committee it has come out very clearly that there are two distinct classes of medical aid associations-one which is worked 
by insurance or other commercial companies, while the others are developments of the great friendly societies.

Commerchal Medical Aid Associations.

With insurance and commercial companies which form and utilise a medical aid branch with the main object of furthering their own commercial ends, and of enabling their canvassers and touters to catch members, who are ever pleased to be led to believe that they will be able to obtain good medical attendance for a few pence, there can be no sympathy; and it is certain that no words which the General Medical Council can utter will have the smallest influence upon their conduct; whilst the law is in their favour they will last so long as they are successful.

We can only regret that educated medical men can be so misled as to sell themselves to such taskmasters, and to undertake professional work which they must know is not likely to be of much benefit to the public, upon terms which they must feel cannot be possibly be remunerative to themselves, but if you think over the question, you will soon understand that it would be wholly wrong for the General Medical Council to pronounce offhand all men associated with the associations as being guilty of infamous conduct and take them off the Register. We may pity their folly and condemn their action, and at the same time do our best to influence them to mend their ways. The following resolution, which was passed by the General Medical Council on June 6th, may help the cause :

That the Council strongly disapproves of medical practitioners associating themselves with medical aid associations by which systematic canvassing aad.

This resc

This resolution may in the future blossom into something stronger should any special case of systematic canvassing for the purpose of procuring patients come before the notice of the Council.

The Conciliation Board and Friendly Societies.

There is some reason to hope that much good may come from the negotiations which are still in progress between the representatives of the great friendly societies and the Committee of the Council; for the spirit which has animated both parties has been of such a healthy nature as to encourage a hope that good may be evolved out of its deliberations. Indeed I am pleased to report that on April 13th, at the National Conference of Friendly Societies held in London, it was unanimously resolved that the suggestion of the Committee of the General Medical Council should be acted upon, and that a Conciliation Board should be formed, composed of the representatives of the friendly societies and of some members of the medical profession, to discuss all questions which may arise between the societies and the medical profession.

With this Conciliation Board at work I can well believe that much good can come, and that many if not all the difficulties which now exist between the friendly societies and their medical officers will become adjusted. If so, much benefit will be effected for both the public and the profession, and under such circumstances, if the friendly societies work harmoniously, there is reason to believe that the commercial medical aid associations to which I have drawn attention will fall into decadence.

Professional Opinion.

With respect to the medical corporations, the cry of the profession for help under existing difficulties is not neglected, for both Royal Colleges use to the full the ample powers they possess for purging their lists of bad men, and of censuring those on the borderland. They are now, as they have been in the past, always ready to consider any case of real or suspected malconduct when such has been rightly placed before them. But it is to be recognised that these corporations are not prosecuting bodies, and that they expect the evidence of error in any individual case to be so placed before them that they can adjudicate upon the case with safety. The evidence can only be brought under their notice by their own Members, and it is better that such should be brought together by some organisation of medical men rather than by an individual. The essential point is that the evidence should be clearly brought before the notice of the colleges.

As to organisation as a means of correcting the admitted and supposed evils which affect our profession, I may say at once that I am a believer in its value, for it means to my mind self-help, individual or combined, which is likely to be far and away more efficacious in its results than the wild cry to councils and corporations for assistance or reform of which we hear so much.

But this medical organisation must not be laid on trades union lines, and no selfish or unworthy motives should be its motor powers, for the ends to be achieved should be the good of the profession and the benefit of the public generally, since no medical service can surely be of value to the public unless it is based on mutual advantages.

The organisations of which I speak are not, however, to be of an overwhelming kind, although one of them is to be this great British Medical Association, neither are they to be endowed with prosecuting powers. Let the prosecuting powers remain in the hands of the existing defence associations which have by time and experience proved their competency to do the work provided for them, and let the profession give these associations its full support. Indeed, I should like to see every member of the profession a member of one of them.

The organisations or medical societies I am now advocating are to be of a local or district character, and should include, if possible, all the medical men of the district. Their objects should be "professional" and "social," and whilst every effort should be employed to render its medical meetings of value and interest as a medical society, its social meetings should be of no less importance, for, at such, the main purpose should be to so influence one another to give up or adopt all practices such as the society as a body has declared after full discussion and consideration to be either good or bad, and to bring into harmonious and friendly working the medical practitioners of the district. Through the influence of such meetings all vulgar methods of conducting work which injure the profession, although practised only by a few, will probably be soon given up by the offending members, and when the disposition to do so fails to show itself, the suggestion that at the next annual meeting the re-election of the recalcitrant member may have to be considered will probably bring about the desired result; should, however, the nonelection of the offending member be the order of the day, let it be understood that as soon as the reprehensible practices are given up, the erring brother may expect to be re-elected, for the object of the society is to raise the profession in its district, and for this purpose everything like persecuition is to be condemned.

Where Branches of this British Medical Association already exist, I would suggest that they should be used for the purposes indicated, and that each Branch institutes a " social" side. I have used the word " social" instead of "ethical" as commonly employed from the feeling that the word "ethics" has more to do with the morals and manners of the man than with his professional methods, and that the ethical laws by which a medical man is governed differ in no respect from those which are wont to govern our Christian neighbours.

When the Council of one of these Branches finds a difficulty in coming to a decision with respect to any case which has been brought before it, I can see no reason why it should not appeal for help to the Council of the Association with the view of having an assessor appointed to help it in its work, and by so doing the parent Society will be only carrying out the objects of the Association-the good of the profession. Indeed, I believe that by encouraging and acting on this suggestion the public benefit of this great Association would be much enhanced.

When a case comes before a Branch which seems to be beyond its functions or power to adjudicate, with or without an assessor, and the point to be decided appears to bring the offender into conflict with the by-laws or laws of the General Medical Council or one of the corporations-let an appeal to one of these bodies be made by the Council of the Branch, and care be taken that the case is clearly presented. When the medical defence associations can be used for this purpose, let them undertake the work.

Any differences which might spring up between rival doctors would by the Councils of these Branches be readily adjusted, and all questions of difficulty between public bodies and their professional workers be more readily solved, when 
the public know that there is already in existence a professional body, with powers to call to their assistance assessors of authority to take into full consideration the subject in dispute, and to advise accordingly, the question in dispute being considered by the public and professional bodies interested before the final decision is reached.

And here I would like to put in one word of caution, and that is-however united the medical society may be in any question of dispute with laymen, let the society be sure before coming to its decision that it has looked at the matter as fully from its public as from its professional aspect, for the public have their rights, and no professional requirements will ever be allowed to override them.

The scheme I have in outline laid before you is one of selfhelp all round, and if carried out in a reasonable spirit must work for public and professional good, since it is a means of bringing into harmonious action the influence of every local body of practitioners upon its individual members with that of this great British Medical Association, and the General Medical Council with the corporations. By means of the local districts, worked in the manner which has been indicated, the influence of friendly association and discussion must prove beneficial to the district in which it exists ; and the help the parent Association, or one of its Branches, could give by means of assessors would not only be of great value airectly, but would at the same time tend to utilise in a happy way the powers of this organisation for the public good.

The General Medical Council and the great corporations would also be brought into line with the profession as a whole, for the profession would by the scheme laid down be working with them in purifying the whole body, and in so doing would be learning something more of the purposes and objects for which these bodies were originally formed, and by so doing would help the work we all have in hand, professional and public good.

I am well aware of the probability that some of my hearers may say of my remarks what has been said of others similarly delivered-that it is easy for a President to preach from his official position, and to lay down schemes which he may consider calculated to be of use, to help the great body of general practitioners in their troubles-but of what value can they be, since as consultant he knows but little about the wants of the large body of whom he talks.

This may or may not be the case under some circumstances, but I do earnestly ask you to take my remarks for what they are worth, and to consider them carefully before you brush them aside as theoretical and useless; for although a consultant and office holder to both the General Medical Council and Royal College of Surgeons, I am the son of a very successful general practitioner, and the father of another who I trust will be successful. I personally passed through the very unprofitable process of an apprenticeship to a general practitioner, and after taking my diplomas practised generally for geven years, when I passed into hospital and consulting work. I can consequently claim to be in close touch with every branch of professional activity, and have certainly not found as a consultant that my opportunities of knowing the wants and wishes of the general practitioner have in any way been diminished. I trust, therefore, that you will give my suggestions careful thought, for they are based upon a desire to encourage self-help by placing you in a position to help yourselves, and to discourage the cry for outside assistance with the professional apathy which is so inimical to all improvement.

I ask this of you under a conviction that the scheme I have placed before you will prove of benefit both to the public and profession.

Society for Relief of Widows and Orphans of Medical MEN.- The quarterly court of the directors of the Society was held on July rath, the Treasurer, Dr. Potter in the chair. Four new nembers were elected and the deaths of three reported (one an honorary member). There were no fresh applications for grants, and it was resolved that a sum of $f 1,201$ IOs. be distributed as recommended at the last Court to the 49 widows, Io orphans, and the 6 recipients from the Copeland Fund. The expenses of the quarter were $6498 \mathrm{~s}$.

\section{LANCASHIRE AND CHESHIRE BRANCH.}

\section{ON THE DUTY OF THE PROFESSION WITH REGARD TO ALCOHOL. \\ By Charles Macfie, M.D.Edin.,} Bolton.

[AFTER some preliminary observations on the manufacture and chemistry of alcohol, Dr. Macfie spoke as follows:] History of Prohibitive Legislation.

The crying evils arising from the use and abuse of alcohol are ever present with us, and in no diminishing quantity, and the helpless hapless victims caught in its toils are daily reaching out their hands beseechingly to us to snatch them from the overwhelming embrace of the alluring demon. therefore we, as a profession, the servants of the public, and yet the masters and teachers in all that appertains to the well-being of the body, whether in health or disease, assume a grave responsibility when we prescribe or countenance the use of alcohol. The effects of alcoholic beverages were as familiar to the B.C. period as they have been since, but we note that the aim of the philosopher and the physician was to promote a condition of body more resistant to the effect of alcohol, or else to help the individual to throw off its evil effects, rather than to encourage habits of sobriety amongst their clients. We thus have preparatory and recuperative remedies.

In ancient Anglo-Saxon times recourse was mostly had to the treatment of the symptoms of the after-effects of alcohol, such as "swelling of the eyes, unconsciousness, dimness of vision, headache, etc." The methods were mostly derived from ancient Roman practice. The ancient physician, in the treatment of the after-effects, had great faith in emetics, and a cold shower bath followed by a sleep, a shampoo, and the application of various oils or ointments to the head, and a "hair of the dog that bit you," in the shape of various aromatics and stimulants internally-such as in ancient England a small beer, or in more recent times a brandy and soda, or even a wineglassful of Worcester sauce. But governments in ancient times had recourse to repressive measures against the vice of drunkennes:s. The Egyptians flogged and imprisoned. Nebuchadnezzar, King of Babylon, suffered a peculiar sentence for the sin of drunkenness. In ancient Grecian laws for the wine-bibber the physiological minimum was even then prescribed: "Three cups-one for health, one for cheerfulness, and one for sleep." Amputation of the legs, and even the death sentence, have been carried out against the excessive drinker. In Turkey molten lead. has been poured down the throat of the inebriate, and every form of "iniquity, cruelty, and indignity" has been tried and found wanting. But in our own country many and varied have been the restrictions placed on the lover of his cups, and the powerful arm of the Church has been used to enforce them. The law of St. Gildas, enacted at the close of the sixth century, "which sent the drunken monk supperlcss to bed" was probably the first liquor law in this country. gradually the laws became more severe, until at the end of the seventh century laymen were included in their scope, on whom a punishment of fifteen days' penance was imposed; no drinking was allowed in church or at wakes, and tavern drinking was prohibited to the priesthood.

In the latter half of the tenth century King Edgar instituted prohibition:

By reducing the number of the alehouses in the villages, and introduced the custom of the peg. The service of the Devil was had recourse to to keep the people sober in mediæval times. In the time of Edward III the reming the advancing tide with a pitch ork. Local control was then in vogue, and corporations had recourse to all manner of prohibitive measures, such as the Newcastle jacket, the filthy hurdle, ducking in filthy water, the cucking stool, the pillory, the stocks, and the pound, in which three last the culprits were battered with all the "filthy token" of a jeering public. In the reign of Edward the First early closing was enforced, and the quality of the liquor assured by penalties for selling inferior. It was in the reign of James the First that fines were first imposed on those who "tarried long at the bar," and the innkeepers for allowing tippling. Even the use of wines was restricted to those of a certain social status. The dead bodies of drunkards were buried in the that the most repressive measures yet enacted for the reduction of the vice of drunkenness were put in force, and at this time (1660) the excise laws were established, also that ardent spirits came more into use. " $O$, 